\title{
Value for Money and Its Contribution to Technology Based Higher Educational Institution with Special Reference to Southern Tamilnadu-An Empirical Analysis
}

\section{B. Shanmuga Priya}

\begin{abstract}
Technology interventions, technology can keep students engaged in material that they may otherwise not be as interested in. Increased student engagement leads to more effective instruction and more student time on task. The population of the study is students who are studying in various selected Engineering and Arts \& Science Colleges in Southern Tamil Nadu. For the purpose of this study three districts were selected randomly such as Virudhunagar district, Tirunelveli district and Madurai district. 650 students of selected Engineering Colleges and Arts \& Science College are considered for study. This research is Descriptive in nature. More effective time management among instructors and students allows instructors to cover concepts in more depth allowing for a greater student understanding and increased knowledge. Overall, the quality of technology-incorporated instruction is more important than the quantity of technology-incorporated instruction (Wenglinsky, 2005). Effective and efficient functioning of value creation even through knowledge sharing to other providers student users with the support of video conferencing, webminar and repository building activities like video lecture capturing platforms, sustain and offer through various modes of technology based service in uplifting the level best among other providers of higher educational institution. Hence, technology play a major role in learning environment as well as a critical success factor for provider and user holistic institutional development in terms of teaching and learning, research and development and professional development activities. By applying the whole investigation, it demonstrates that most minimal administration gap is happened in "Assurance", "Tangibility" and "Responsiveness" measurements and the greater administration service gap is happened in the Empathy measurement. From the above table reliability in between the minimal to greater administration service gap. So after empathy this reliability play a major role to solve, when service quality gap is concerned. Out of five dimensions reliability play a major role in value for money in terms of time value, prompt solution, incorporating culture. So higher educational institution easily satisfy perception level of students than expectation. This will lead to exceed student customer satisfaction.
\end{abstract}

Keywords - Technology, Reliability, value for money, Service Quality Dimensions

\section{INTRODUCTION}

India has expressed that the present arrangement of Higher education does not fill the need for which it has been begun. All in all instruction itself has turned out to be so gainful a business that quality is lost in the expansion of amount of expert foundations with standard framework and politicization stoking the terminate of ruin framework,

\section{Revised Manuscript Received on December 16, 2019.}

B. Shanmuga Priya, Department of Business Administration, Kalasalingam Business School, Kalasalingam Academy of Research and Education, Krishnan koil
In this manner expanding unemployment of graduates without speedy help to relieve their sufferings in the employment market of the nation. In this way, the downsides of the Higher education framework underscore the requirement for changes to make it advantageous and useful to all concerned. By China, India is the most populated nation on the planet. Actually there is a lot of surge and rivalry in each field. In this way, hurry to specialized and Higher education has expanded as extension for expressions and science has turned out to be lesser and lesser because of absence of changes and up degree in the course structure and materials as indicated by the improvements of the world. Additionally, capability in Higher education gives added preferred standpoint to confront effectively rivalry in the occupation advertise. Reason for the training is all round improvement of identity is the motivation behind instruction. However, the present day training is granted genuine information of life, world and helping one remain all alone leg or enhancing the ability of an understudy by which one can accomplish trees in the field one is intrigued. students are the main user of education, but there are other stakeholders ranging from parents, prospective employers and society as a whole; and all of them have a vested interest in what they perceive as how successful and appropriate is the education for the needs of the students. Student perception of quality is an important variable and may be related to almost any definition of educational quality Gallifa and Batalle proposed slightly redefined dimensions of quality based on Parasuraman et al. mode M. B. Holbrook [2005, p. 46] defines value as an "interactive, relativistic, preference and experience". Such concepts allow one to focus on actions and experiences and not simply costs and benefits. Much of the literature has also moved away from the transactioncentric understanding of value in exchange towards the concept of value in use. This concept describes costumer value as that which is experienced by the customer in use situations, rather than what is determined by the producer for exchange [Haynes and Grugulis, 2014, p. 177]. S. L. Vargo and R. F. Lusch [2004b, 2008] also contend that value is perceived and determined by the customer on the basis of value in use. Modern understanding of value in marketing and management literature emphasises the processual nature of its creation. It is suggested that the firm, network partners and customers co-create value through interactions. value for time-It is more than possible that when an educational experience is appraised in relation to a value, this is based on its existential value (and related costs) rather than simply its economic value. So, Higher educational institutions use the

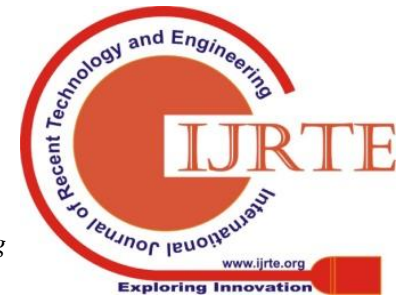


technology enabled service for their existential value for the co-creation of student end goal achievement. Positioning the mind set of all stakeholders among the competitive providers of Higher educational institution. The best and efficient provider invest in technology based services to student users. Through the providers save time of student user as a value for their money and get good return. The objective of the paper is to study the contribution and considerable role of technology in value added service in terms of higher educational institutions quality and to assess an impact of reliability based service quality gap among service quality dimensions on value creation for service provider as well as the student perspective.

\section{REVIEW OF LITERATURE}

Michael Tomlinson. (2018), developed a critical analysis of the dominant meanings of value in marketised higher education. In policy terms, this has become informed by the logics of the measured market whereby value has become synonymous with economic return and institutional accountability. The notion of value is one which permeates many discussions on the purpose of higher education and the perceived benefits it confers onto individuals and society as a whole. This, however, remains largely implicit and unearthing the specific meaning of value(and values) clearly presents challenges. The study examined a variety of concepts relevant to discussion of the value of higher education, including the relationship between value and quality, consumerism, goods and performativity. In each case, it unpacks the meanings and implications for the relationship between students and institutions, particularly at a time when this is seen to be increasingly transactional. It then outlines an alternative value framing to the utilitarian 'value for money' so prevalent in much market-driven policy.

Jian Han Lim et al. (2017) denoted that Internet of Things (IoT) with the concept of integrating connectivity, sensors, data analysis and decision making in an underlying framework has ease many real world problems. Application of IoT for education purpose. Student's behavior and performance in the class is always the main concern of every educator. The instructors are responsible to ensure the smoothness of the classroom activities alongside with monitoring the students' attendance, attention, and activities like entering or leaving the classroom. Manual observation on these could affect the teaching and learning process and causes the distraction from the main syllabus. With the incorporation of IoT devices and computational algorithms such as computer vision techniques, machine learning and data analysis, it can ease the monitoring task and the analysis of students' performance in the class. In advance, it can perform automated real-time observation on the student's behavior through network and react immediately to critical situation if necessary. Nonetheless, the students' long term performance can be recorded and the data can be used for continuous assessment in the future. The study proposed an IoT framework that focused on three analysis modules: face recognition, motion analysis, and behaviour understanding to effectively perform classroom monitoring tasks such as taking attendance, identify entering and leaving activities and analyse the students concentration level.
Reetha.S and Dr.P.Visu. (2017) denoted that the attendance maintenance system is the major performance evaluation of the student. In recent periods, the student attendance is maintained in the system manually and updated in the particular college server. In proposed system, the study implemented an IOT based web camera technique. In this the student image is captured while registration process and saved in the database with all the relevant and personal information. To calculate the attendance the student image is captured in which the details are fetched from the database. The daily attendance is updated in the database by the administrator. When the particular student image is captured, then the details is fetched from the database. The student attendance can be updated to database and database send the attendance details to parent by mobile sms system.

Vikrant Kumar Kaushik et al. (2017) stated that the most common problem faced by students these days is related to Attendance. They get short of attendance due to several factors beyond their control as in the case of an emergency, where they might not be able to send their leave application. There are times when due to lack of coordination with the concerned authorities, they miss the attendance of several important in-campus and off-campus activities such as events, workshops, seminars etc. In some cases, they do not even get the information about the upcoming events which would be beneficial to them. The proposed system automates the existing system. It decreases the paper work and makes the record maintenance process easy by replacing all the traditional methods by computerized techniques. There are features like email notifications, automatic approval of leave, report generators etc in this system. Leave Management application will reduce paper work and maintain records in a more efficient way.

Husain SalilulAkareem and Syed ShahadatHossain. (2016) denoted that in recent decades, the commercialization of education has become more apparent and the need for using marketing tools is greater than before. This study aims to identify the demographic and background information of students that differentiate their perception about quality of higher education. A sample of 432students was taken from five top private universities of Bangladesh to evaluate their perception toward dimensions of higher education. Multinomial regression analysis was conducted to identify the characteristics of students which make their perception about quality of higher education dissimilar. The findings showed that status of students for scholarship, extracurricular activities, parents' education, age, previous result, and university they study in have a significant influence on perception about quality of higher education. Part-time job status

has moderate influence on the students' perception. This research carried value to education policy-makers and university authorities. They can use these findings to formulate regulations, and target specific groups of students to ensure favorable academic environment and increase the brand image of their institutions.

Nate Johnson. (2016) stated that sometimes what colleges and universities have to do as businesses to generate revenue is consistent with their academic goals. But often they have to choose one over the other. "Cash-for-credits" does not, however, provide a sustainable

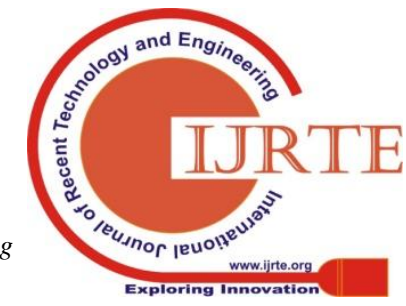


foundation for other things that public higher education needs to do: focus on low-income students who cannot afford the full cost, offer courses in high-cost technical and scientific disciplines, invest in advising and long-term or coordinate with potential employers. In the long term, changing federal aid policy may be the most effective way to get higher education to focus less on managing enrollment and more on managing outcomes. There are three common ways of talking about higher education budgets, each with different implications for incentives: the total institutional budget, the "core" educational budget, and the student budget. Well-structured incentives should take each of the three budget perspectives into account, but often are geared more toward one than the other.

SagarRajebhosale et al. (2016), objective is to develop an application that provides a smart and easy way for the execution of several academic operations to provide students with information regarding complaints, any placement activities, general notices, and important notices regarding all departments. The application has four types of users: Student, Teachers, H.O.D., and Principal. Each type of user will have own application view respective to their type. They have privileges according to their designation or their types and have rights to post things on application so that other users can view that if they are supposed to or have permission to view it. They also provide multiple features so that they can have all the academic things and information at one location. For H.O.D. and principal will provide features to look overall the operations over the applications and have control on it.

P. Shanmugapriya et al. (2016) stated that the prime goal was to develop a reliable student performance monitoring system so that the mentors at educational institutions can monitor their students, who are either in campus or out campus executing their normal daily life activities. In this work they presented a mobile device based wireless students performance monitoring system that can provide real time online information about performance, attitude, sports participation, cultural activities involvement, state, national level participations of various events of a student and etc. Their proposed system is designed to measure and monitor important academic and non academic data of a student in order to accurately describe the status of her/his performance and ability to their successful carrier ahead. The student's academic and non-academic details, attitude, IQ status, aptitude, sport, and other National/International event participation details etc are stored, Evaluated, Monitored and controlled by LAYAH UI system.

SnehalKekane et al. (2016), conducted a survey of work done in existing systems for student performance analysis and monitoring. As well as the survey to understand and analyze the existing system and the algorithms that are used in it and to propose a system that will analyze student performance and will guide them by displaying the areas where they need improvement, in order to contribute to a student's overall development by generating a score card for the same. The study presented the analysis of student performance on the basis of academic performance, research and innovation, self-development and extra-curricular activities. Performance Analyzer, Score Card, Student Development, Student Performance, Student, Classification, Association rules. academic planning, give credit for work at other institutions

Chris Kila. (2015) stated that the developments in Technology in recent years has grown rapidly having a lot of impact on the lives of humans. Universities across the globe have been able to study and do research with the ease of improved technological facilities in the Information and Communication Technology (ICT). University students are exposed to the changing world and the ongoing change in technology taking place. Such improvements in technology has replaced the use of traditional methods of education which uses chalkboard, whiteboard and hard copy textbooks. This changes have brought a lot of significance to university students enhancing a student's academic performance and on the other hand contributing to a decline in the progress of a student's academic study as well. The study concluded that Information Technology and Communication plays a major role in

improving the academic standards of a university and its students to meet the growing needs of the job market in the technological influenced century. Therefore universities should put more attention into improving ICT facilities so that students will

be exposed to ICT before going out into the workforce.

\section{Evolution of Educational Technology Tools}

Historically, as technology has advanced, its integration into education has increased. Throughout the last century, teachers have implemented many different forms of educational technology tools into their instruction. With each of these technologies, the importance of using them effectively is essential to instructional integration. "Bringing another innovation into the classroom so as to change instructing and learning has been a long-standing custom in training. Classrooms and instructors alike have seen innovations (e.g., television, radio, etc.) come and go, innovations tried and tossed out" (Groff \& Mouza, 2008, pp. 21-22). In their time, technologies such as the radio, film, and television were considered progressive technologies that enlivened spoken and printed work (Cuban, 1986). However, due to barriers such as lack of equipment, poor quality of equipment in schools, and difficulty with scheduling radio or television time in schools, none of these technologies were as successful as predicted (Cuban, 1986). These educational reform efforts never garnered widespread adoption. To the disappointment of educational charities and even the U.S. Office of Education who financially invested in these educational technology initiatives, these tools never evolved into mainstream educational programming tools as many had hoped. Additionally, early educational technology tools failed to make books obsolete in schools as Thomas Edison predicted they would in 1913 (Cuban, 1986). In the 1980s, the computer entered the classroom, touted as another instructional technology (Aslan \& Reigeluth, 2011) With this new technology came new educational opportunities. Educational leaders envisioned and projected high expectations for the use of 7 computers and other technology for the improvement of teaching and learning (Keengwe, Onchwari, \& Wachira, 2008). In 1985, there was at least one microcomputer available for instruction in $92 \%$ of secondary schools and $82 \%$ of elementary schools (Aslan \& Reigeluth, 2011). The addition of the computer in the 
education classroom increased the technology tools available for instructional purposes

Overall, technology has been integrated into education in a variety of ways. As technology use has progressed, its incorporation into instruction has increased. From computers to handheld devices, such as tablets, today's students are using technology to facilitate learning more than ever before. In addition to using a variety of types of technology, technology-rich instruction is also taking on a variety of appearances. Technologies such as blogs, wikis, podcasts, and webquests are being introduced into teaching and learning in all subject areas on a regular basis.

\section{Incorporating Technology in Education}

In today's technology-rich world, the role of technology in education is continually becoming more significant. According to Raines and Clark (2011), the use of technology in the classroom is rapidly increasing. Instructors are now using technology in more ways than ever before. Educators in all levels of education, from K-12 to post-secondary, are finding ways to enhance instruction through the use of educational technology tools. In higher education, educators are using technology tools for instructional purposes, such as presenting content, student collaboration, and learning assessments, as well as other tasks such as recording grades and communicating with students (Rother, 2004). Instructors in higher education are using these tools to facilitate teaching in synchronous and asynchronous environments. Increased use of educational technology tools can aid instruction and encourage student learning. Although technology continues to transform instructional practices, many technologies have remained supplemental resources in the educational classroom, especially in higher education. Since many new educational technology tools have not been widely adopted by educators, it is hard to know how they are best used for instructional purposes or how they can most effectively improve students' learning experience and increase student course satisfaction (Conole \& Dyke, 2004). Even though technology can be a powerful tool and the advantages to using it in the classroom are abundant, instructors should make sure to use technology tools sensibly in ways that it is beneficial to instruction (Cowan, 2008). Effective use of technology in instruction can lead to greater student productivity and instructor efficiency. Improving instruction using technology enables deeper learning. Thus it is imperative that instructors are aware of the most effective uses of educational technology tools to facilitate online student learning in higher education. In addition, incorporating technology into instruction often presents material in a means that is more interesting and appealing to students (Lei \& Zhao, 2008). Some researchers suggest that this is due to a novelty effect; using shorter technology interventions often shows more promising results in regards to increased achievement. Interest created from the novelty of technology can decrease with time often resulting in decreased motivation ( $\mathrm{Li} \& \mathrm{Ma}, 2010$ ). With short technology interventions, technology can keep students engaged in material that they may otherwise not be as interested in. Increased student engagement leads to more effective instruction and more student time on task. More effective time management among instructors and students allows instructors to cover concepts in more depth allowing for a greater student understanding and increased knowledge. Overall, the quality of technology-incorporated instruction is more important than the quantity of technology-incorporated instruction (Wenglinsky, 2005).

Effective and efficient functioning of value creation even through knowledge sharing to other providers student users with the support of video conferencing, webminar and repository building activities like video lecture capturing platforms, sustain and offer through various modes of technology based service in uplifting the level best among other providers of higher educational institution. Hence, technology play a major role in learning environment as well as a critical success factor for provider and user holistic institutional development in terms of teaching and learning, research and development and professional development activities.

\section{EVOLUTION OF ONLINE LEARNING}

As new technology innovations evolve, new teaching methods, such as online learning, emerge. Online learning emerged from distance education. For many decades, distance education has been continuously changing and evolving as technology used to deliver the instruction has evolved (Bower \& Hardy, 2004). Distance education progressed sequentially from correspondence education to instructional film followed by educational radio and later instructional television (Cuban, 1986). In recent years, distance education evolved to video-conferencing and eventually web-based instruction (Bower \& Hardy, 2004). Educators have used correspondence education to facilitate distance learning for almost three centuries. As early as the 1700 s, educators offered instruction via correspondence education (Bower \& Hardy, 2004). Over the centuries, correspondence education has expanded educational opportunities to those who were housebound, lived in remote areas, or wanted to study at their own pace. Instructors and students would correspond and exchange work through the mail. The postal service facilitated this education and expanded learning, providing opportunities to individuals who may have otherwise been unable to obtain education (Bower \& Hardy, 2004).

During the twentieth century, distance education changed dramatically due to the invention of new technologies and the emergence of online learning. New technologies allowed instruction to be delivered at a distance in new ways. Distance education evolved into real-time audio-graphics and video-conferencing and eventually into the interactive, web-based online learning courses that higher education learners experience today (Greenberg, 2004). The evolution of distance education continued to transform instruction and provide educational opportunities to learners who were otherwise unable to access the instruction (Barbour, 2007; Greenberg, 2004). Video-conferencing provided opportunities for students and instructors to gather in real time at different locations by transmitting communication across distances. "New innovation is progressively being utilized to supplement set up instruction rehearses and grow better approaches for adapting, for example, online training" (Baghdadi, 2011). Today's online learning opportunities

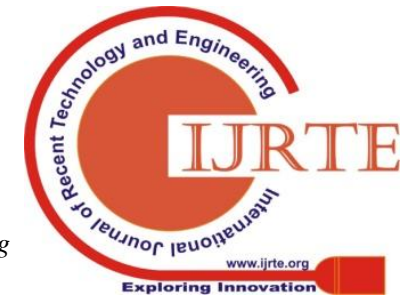


are multifaceted and provide instruction to more higher education learners in more places than before through both synchronous and asynchronous instruction (Barbour, 2007; Greenberg, 2004).

\section{USE OF TECHNOLOGY TOOLS IN HIGHER EDUCATION LMS}

Today, many of the educational technology tools used in higher education online courses are part of LMS (Yueh \& Hsu, 2008). Instructors use LMS tools such as forums, wikis, lessons, and chat features to develop well-designed online learning environments. These tools aid educators to facilitate learning in the higher education online environment. Since the emergence of LMS in education, the educational technology tools incorporated into LMS have been enhanced and become more sophisticated. LMS were introduced in the 1990s as an assortment of multimedia and internet developments. Over the past two decades, LMS have evolved into more interactive learning environments that have been adopted by the majority of universities around the world (Coates et al., 2005). According to a 2014 EDUCAUSE Center for Analysis and Research (ECAR) study, "99\% of institutions have an LMS in place" (Dahlstrom, Brooks, \& Bichsel, 2014, p. 4).

There are three types of interaction that facilitate learning: student-content, student instructor, and student-student; distance education jeopardizes the latter two (Lou, Bernard, \& Abrami, 2006). In addition to creating more interactive learning opportunities, the use of LMS tools in higher education can facilitate student-instructor interaction as well as student student interaction in a higher education online environment (Lonn \& Teasley, 2009). Since LMS are webbased systems, they can be used to facilitate access to course content and administration anytime and anywhere. The webbased delivery platform allows students to access the LMS from any time and place that is convenient (Black, Beck, Dawson, Jinks, \& DiPietro, 2007; Cavus \& Ibrahim, 2007). By using both asynchronous and synchronous technologies, LMS tools provide a variety of ways to interact in higher education online courses. LMS "give apparatuses to course organization and academic elements of varying refinement and potential" (Coates et al., 2005, pp. 20-21). Although LMS have been widely adopted in post-secondary education, very little is known about how they are being used and how they benefit student learning and satisfaction (Koszalka \& Ganesan, 2004).

The growth in adoption of LMS has triggered an increased incorporation of LMS tools in higher education online instruction. The tools contained in LMS can facilitate interaction between students and instructors, as well as among students (Cavus \& Ibrahim, 2007; West, Waddoups, \& Graham, 2007). Interactions in the LMS virtual learning environments create innovative opportunities which can facilitate learning (Dutton, Cheong, \& Park, 2004). LMS provide a mechanism for "educators and understudies to share instructional materials, make class declarations, submit and return course assignments, and speak with each other on the

web" (Lonn \& Teasley, 2009, p. 686). Creating an interactive environment within the LMS sparks students to be more engaged with the course content; greater engagement typically leads to improved student learning (Wang, 2007). Herse and Lee (2005) assert that virtual learning environments like LMS "can be utilized as an impetus for self-reflection and to assist encourage change from aloof to dynamic learning" (p. 51). By developing an active learning environment, higher education instructors can better facilitate online student learning. According to Dahlstrom et al. (2014), "71\% of faculty say the LMS is a very useful tool to enhance student learning" (p. 4).

The way that LMS tools are incorporated into instruction is typically left to the discretion of the instructor (Govindasamy, 2001). LMS usually include a number of "genuinely nonexclusive devices, for example, test/test choices, discussions, a booking apparatus, synergistic work space and evaluating components" (Black et al., 2007, p. 35). These tools incorporated in LMS allow instructors "to create intelligent website pages, transfer and incorporate advanced assets, and create evaluation undertakings and spaces for online examination" (Coates et al., 2005, p. 22). Higher education instructors design their online courses in LMS by uploading course content and providing students access to it. Additionally, instructors can observe their students' level of interaction in the LMS and keep track of students' success rate. The LMS environment is also beneficial to higher education online students allowing for opportunities to "concentrate the course notes at their own places of study, meet their educators and colleagues in virtual classrooms, and furthermore set themselves up for the examinations by unraveling individual test questions at whatever point they feel like" (Cavus \& Ibrahim, 2007, p. 302).

\section{NEED OF THE STUDY}

The importance of the review includes to the academic study the utilization of evaluation practices in grown-up training. In particular, the exploration gives a superior comprehension of the occurrence and nature of different appraisal strategies utilized as a part of the higher educational instituion setting. Also from admission to academic, appraisal, research everything rely on the technology enabled services for the overall performance of higher educational institutions. So technology is the main resource generation way to create value for money. Hence, roots for competitive advantage including the tangible resource based preparedness of higher educational institutions in the form of technology. Then the human resource also in a position to incorporate and blend with this technology oriented practices to adopt and upgrade their skill set to sustain in the competitive advantage continuously. In connection with resource and capability in the strategical way of win over the competitive situation in this perspective. Everywhere these things are increasing in nature. So this study is the need of hour to know, how to create value for money for the higher educational service provider as well as the student perspective.

\section{STATEMENT OF THE PROBLEM}

Different research ponders have indicated wide hole between the measurement of customer behavior and service quality in Higher Educational institutions. The variation with the educational sector of SQD (Service Quality Dimensions) segment varies in segment wise satisfying the customer satisfaction. Because of this reality an exhaustive review is required to

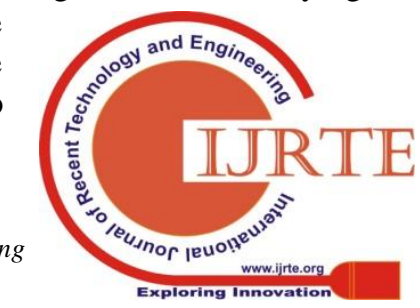


concentrate the client conduct and administration quality offered by the higher instructive organizations to their forthcoming clients. This exploration is required to assess the apparent level and desire (sought) level of the clients towards the administration rendered by various higher educational institutions of the selected districts of southern Tamil Nadu.

Different research contemplates have demonstrated wide crevice between the estimation of client behaviuor and administration quality in Higher Educational organizations. The variety with the instructive area of SQD (Service Quality Dimensions) portion fluctuates in fragment savvy fulfilling the consumer loyalty. Because of this reality a far reaching study is required to concentrate the client behaviuor and benefit quality offered by the higher instructive establishments to their planned clients. This exploration is required to assess the apparent level and desire (wanted) level of the clients towards the administration rendered by different Higher instructive foundations of the chose areas of southern TamilNadu. As per NAAC one of the focus advance utilization of innovation is possible through technology.

\section{HYPOTHESIS OF THE STUDY}

1. There is no evidence to indicate that customer's perceptions will be lower than expectations of the service

\section{VIII.METHODOLOGY}

This research is Descriptive in nature since it this research describes perceived service quality performance and the expected service quality of the higher educational institutions customer.

\section{SAMPLING DESIGN \\ Population}

The population of the study is students who are studying in various selected Engineering and Arts \& Science Colleges in Southern Tamil Nadu. For the purpose of this study three districts were selected randomly such as Virudhunagar district, Tirunelveli district and Madurai district. All the students of selected Engineering Colleges and Arts \& Science College are considered for study.

\section{Sample Size}

According to http://www.raosoft.com/samplesize.html sample size calculator recommends sample size is 650 with $5 \%$ of acceptable errors and with a confidence level of $95 \%$.

\section{Sampling Technique:}

The sampling technique followed is Disproportionate Stratified Random Sampling.

\section{DATA COLLECTION}

Primary Source of Data Collection - First hand data to be collected from customers of all selected district of higher educational institutions.

Secondary Data - Review of literature collected from journals, magazines, websites related to higher educational institutions.

\section{AREA OF THE RESEARCH}

The Following are the selected districts of southern Tamil Nadu will be taken for this research purpose for collecting samples, they are

1. Virudhunagar district,

2. Tirunelvelli district and

3. Madurai district.

\section{STATISTICAL TOOLS}

The following statistical tools were applied in this study as follows,

$$
\begin{aligned}
& \text { - Confirmatory } \\
& \text { Analysis } \\
& \text { - } \quad \text { Gap Analysis } \\
& \text { - Multiple regression }
\end{aligned}
$$

\section{DATA ANALYSIS AND INTERPRETATION}

\begin{tabular}{|c|c|c|c|}
\hline $\begin{array}{l}\text { Perception } \\
\text { Scale }\end{array}$ & $\begin{array}{l}\text { Cronbac } \\
\text { h's Alpha }\end{array}$ & Expectation Scale & $\begin{array}{l}\text { Cronbach's } \\
\text { Alpha }\end{array}$ \\
\hline $\begin{array}{l}\text { To accomplish } \\
\text { something in a } \\
\text { specific time } \\
\text { when it has } \\
\text { guaranteed to } \\
\text { do as such }\end{array}$ & 0.955 & $\begin{array}{l}\text { To accomplish } \\
\text { something in a } \\
\text { specific time when } \\
\text { it has guaranteed to } \\
\text { do as such }\end{array}$ & 0.958 \\
\hline $\begin{array}{l}\text { To investigate } \\
\text { understudy's } \\
\text { issues and } \\
\text { attempt to give } \\
\text { an answer } \\
\text { immediately }\end{array}$ & 0.953 & $\begin{array}{l}\text { To investigate } \\
\text { understudy's issues } \\
\text { and attempt to give } \\
\text { an answer } \\
\text { immediately }\end{array}$ & 0.958 \\
\hline $\begin{array}{l}\text { To provide its } \\
\text { services } \\
\text { without errors }\end{array}$ & 0.953 & $\begin{array}{l}\text { To provide its } \\
\text { services without } \\
\text { errors }\end{array}$ & 0.958 \\
\hline $\begin{array}{l}\text { To have high } \\
\text { teaching } \\
\text { standards and } \\
\text { quality } \\
\text { academics }\end{array}$ & 0.954 & $\begin{array}{lr}\text { To have high } \\
\text { teaching } & \text { standards } \\
\text { and } & \text { quality } \\
\text { academics } & \end{array}$ & 0.958 \\
\hline $\begin{array}{l}\text { To provide } \\
\text { 'value for } \\
\text { money' } \\
\text { education } \\
\text { services }\end{array}$ & 0.954 & $\begin{array}{l}\text { To provide 'value } \\
\text { for money' } \\
\text { education services }\end{array}$ & 0.959 \\
\hline $\begin{array}{l}\text { To convey its } \\
\text { administrations } \\
\text { in generally } \\
\text { little and } \\
\text { reasonable class } \\
\text { sizes }\end{array}$ & 0.954 & $\begin{array}{l}\text { To convey its } \\
\text { administrations in } \\
\text { generally little and } \\
\text { reasonable class } \\
\text { sizes }\end{array}$ & 0.958 \\
\hline Reliability & 0.952 & Reliability & 0.957 \\
\hline
\end{tabular}

Table I shows that Estimation of the Cronbach's Alpa value - Reliability

DEMOGRAPHIC CHARACTERISTICS OF THE STUDY

Table II shows that Gender wise classification of respondent 


\begin{tabular}{|l|l|l|}
\hline Gender & Frequency & Percent \\
\hline Male & 299 & 46 \\
\hline Female & 351 & 54 \\
\hline Total & 650 & 100.0 \\
\hline
\end{tabular}

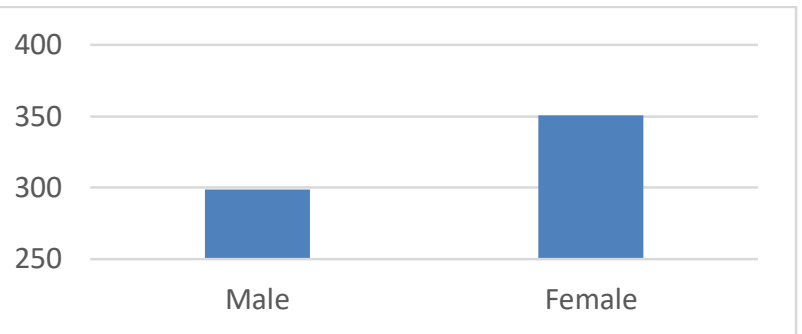

Figure 1 shows that Gender wise classification of respondent

\section{Inference}

From the above table it is identified that, out of 650 respondents, 351 respondents are Female (54\%) and the remaining 299 respondents are Male (46\%).

\section{Table III shows that Age Wise Classification}

\begin{tabular}{|l|l|l|}
\hline Age Group & Frequency & Percent \\
\hline 17 to 21 Years & 295 & 45 \\
\hline 21 to 25Years & 265 & 40 \\
\hline 26 to 30 Years & 90 & 15 \\
\hline Total & 650 & 100.0 \\
\hline
\end{tabular}

Table V shows that factors of service quality in reliability

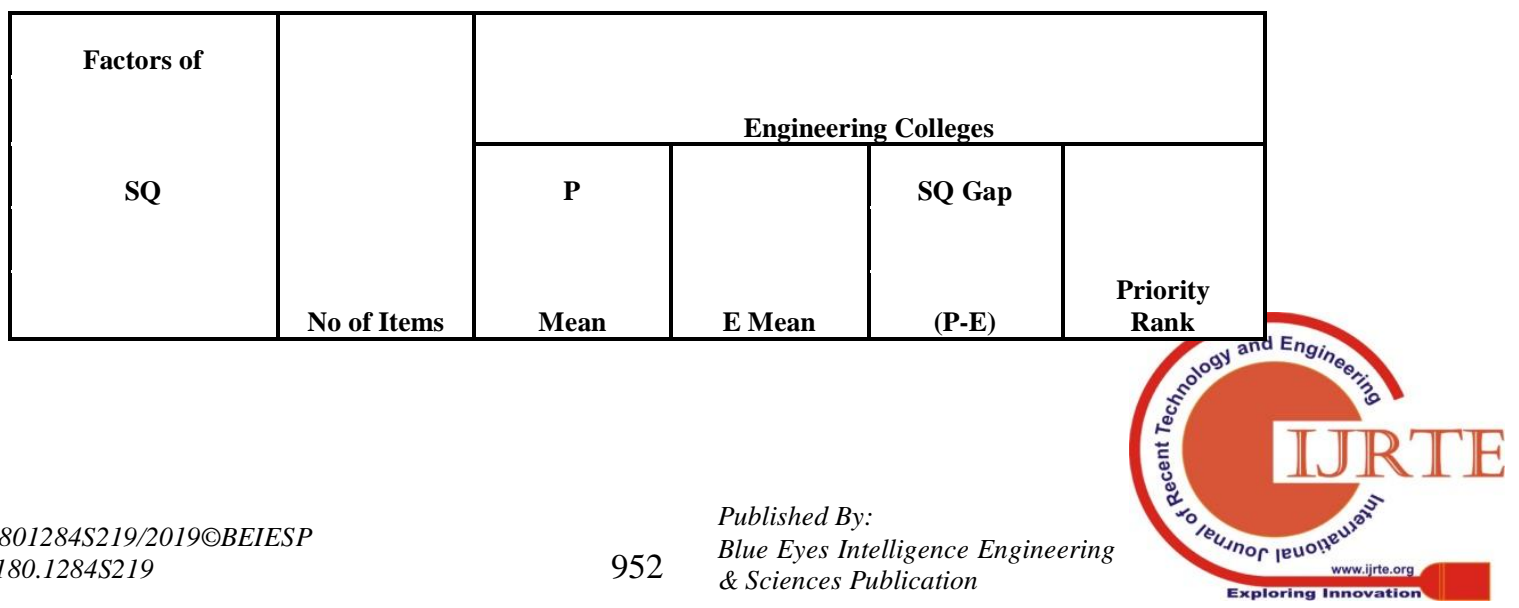

Figure 2 shows that age wise classification of respondent

\section{Inference}

From the above table it is evidenced that, out of 650 respondents, 295 respondents are in the age group of 17 to 21 years, 265 respondents are in the age group of 21 to 25 years and remaining 90 respondents are in the age group between 26 to 30 years.

Table IV shows that Weighted Average Method Selected Factors

\begin{tabular}{|c|c|c|c|c|}
\hline 1 & $\begin{array}{l}\text { To do something in a certain time } \\
\text { when it has promised to do so }\end{array}$ & 5.2330 & 1 & Agree \\
\hline 2 & $\begin{array}{l}\text { To look into student's problems and } \\
\text { try to provide a solution promptly }\end{array}$ & 5.2102 & 3 & Agree \\
\hline 3 & To provide its services without errors & 5.2137 & 2 & Agree \\
\hline 4 & $\begin{array}{l}\text { To have high teaching standards and } \\
\text { quality academics }\end{array}$ & 5.1676 & 4 & Agree \\
\hline 5 & $\begin{array}{l}\text { To provide 'value for money' } \\
\text { education services }\end{array}$ & 5.0114 & 6 & Agree \\
\hline 6 & $\begin{array}{l}\text { To deliver its services in } \\
\text { relatively small and } \\
\text { manageable class sizes }\end{array}$ & 5.0739 & 5 & Agree \\
\hline \multicolumn{2}{|c|}{ RELIABILITY } & 5.1516 & & Agree \\
\hline
\end{tabular}


Value for Money and Its Contribution to Technology Based Higher Educational Institution with Special Reference to Southern Tamilnadu-An Empirical Analysis

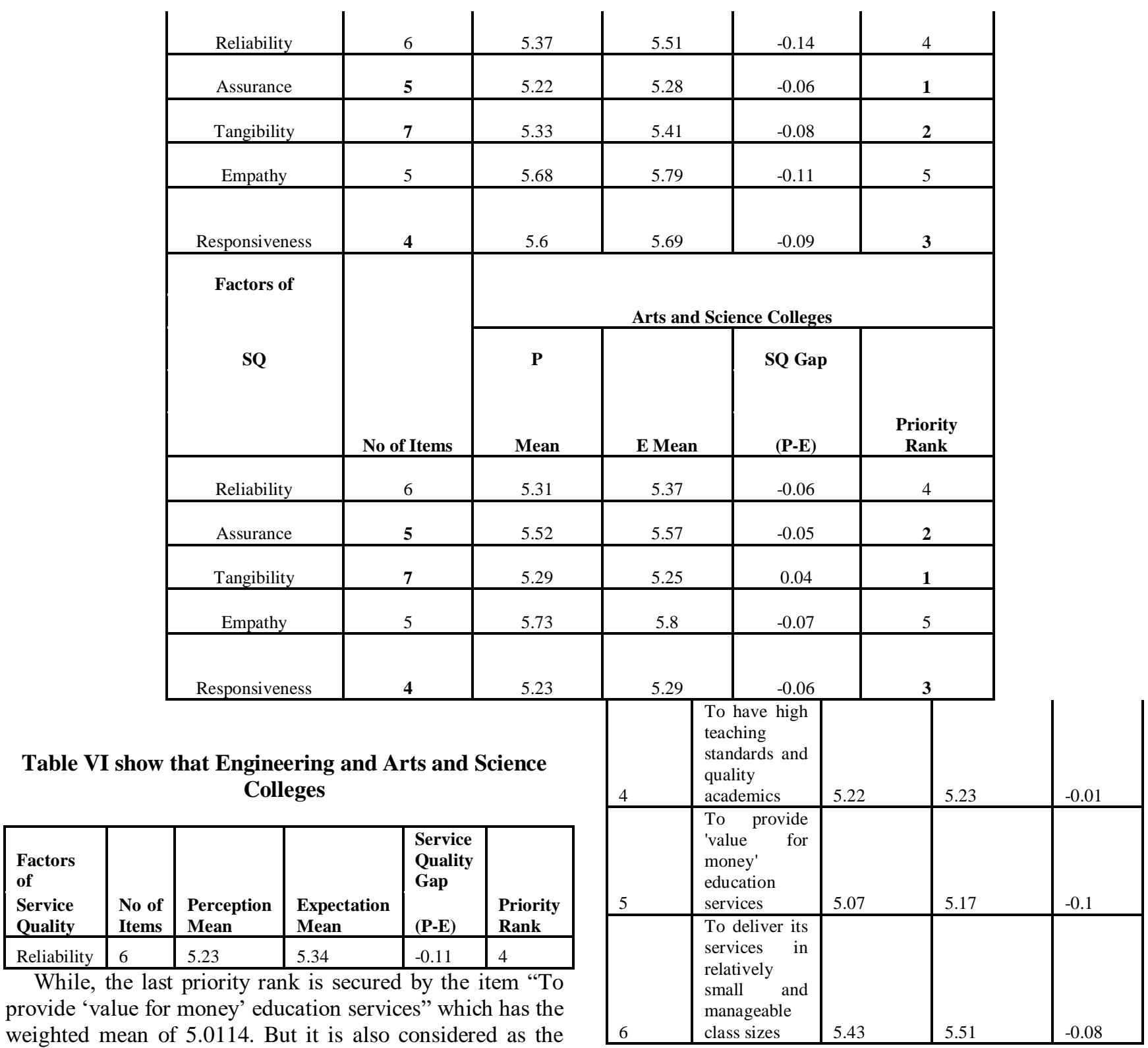

Table VI show that Engineering and Arts and Science Colleges

While, the last priority rank is secured by the item "To provide 'value for money' education services" which has the weighted mean of 5.0114. But it is also considered as the agreeable statement by the respondents. Since all the statements are agreeable, this item has secured the last priority rank. Overall, all the statements that assess SQ are agreeable and it is revealed from the composite mean value of 5.2024 .

Table VII Shows that Service Gap Analysis Testing of Hypothesis:

\begin{tabular}{|c|c|c|c|c|}
\hline SI.NO & $\begin{array}{l}\text { Items of } \\
\text { SERVQUAL } \\
\text { Instrument }\end{array}$ & $\begin{array}{l}\text { Perception } \\
\text { mean }\end{array}$ & $\begin{array}{l}\text { Expectation } \\
\text { mean }\end{array}$ & $\begin{array}{l}\text { Service } \\
\text { gap } \\
\text { (P-E) }\end{array}$ \\
\hline 1 & $\begin{array}{l}\text { To do } \\
\text { something in } \\
\text { a certain time } \\
\text { when it has } \\
\text { promised to } \\
\text { do so. }\end{array}$ & 5.47 & 5.53 & -0.06 \\
\hline 2 & $\begin{array}{l}\text { To look into } \\
\text { student's } \\
\text { problems and } \\
\text { try to provide } \\
\text { a solution } \\
\text { promptly }\end{array}$ & 5.34 & 5.41 & -0.07 \\
\hline 3 & $\begin{array}{l}\text { To provide its } \\
\text { services } \\
\text { without errors }\end{array}$ & 5.03 & 5.21 & -0.18 \\
\hline
\end{tabular}

$\mathrm{H}$ : There is no evidence to indicate that customer's perceptions will be lower than expectations of the service $\mathrm{H}_{\mathrm{A}}$ : There is an evidence to indicate that customer's perceptions will be lower than expectations of the service

Service Gap Difference between Perception and Expectation level

From the above table, it is shown that the general SERVQUAL score which is the aftereffect of normal recognition score short normal desire score that is gotten from the 27 matched proclamations. Utilizing a combined $\mathrm{t}$ test shows a factually noteworthy contrast on the 27 proclamations which are analyzed and it is inferred that the theory $\mathrm{H}$ is rejected. The option speculation is acknowledged. So there is a confirmation to demonstrate that client's recognition is lower than desire of the administration.

The calculated mean ratings of perception and expectation of SERVQUAL score is the normal observation short normal desire score of the five SQ measurement is appeared in the table. By applying the whole investigation, it demonstrates that most 
minimal administration gap is happened in "Assurance", "Tangibility" and "Responsiveness" measurements and the greater administration service gap is happened in the Empathy measurement. From the above table reliability in between the minimal to greater administration service gap. So after empathy this reliability play a major role to solve, when service quality gap is concerned.

\section{Table VIII show that Structural paths for perception} rating

\begin{tabular}{|l|l|l|l|l|l|l|}
\hline \multicolumn{2}{|l|}{$\begin{array}{l}\text { Structural Paths } \\
\text { for Perception }\end{array}$} & $\begin{array}{l}\text { Beta } \\
\text { Ratings } \\
\text { Estimate } \\
\text { ) }\end{array}$ & S.E. & $\begin{array}{l}\text { C.R } \\
\cdot\end{array}$ & $\begin{array}{l}\text { P } \\
\text { valu } \\
\text { e }\end{array}$ \\
\hline $\begin{array}{l}\text { OVER } \\
\text { ALLSQ }\end{array}$ & $<---$ & $\begin{array}{l}\text { SQD' } \\
\text { s }\end{array}$ & 0.33 & $\begin{array}{l}0.09 \\
5\end{array}$ & 14.548 & 0.000 \\
\hline $\begin{array}{l}\text { Reliabilit } \\
\text { y }\end{array}$ & S--- & SQD' & 0.23 & $\begin{array}{l}0.08 \\
6\end{array}$ & 11.900 & 0.000 \\
\hline
\end{tabular}

\section{CONClusion}

Firstly, To do something in a certain time when it has promised to do so based reliability factor focus on the responsibility of proactive promotional core values is play a very important key performance area, second important factor is to provide its services without error which means that responsibility and powers clear and transparent flexible enough to respond to issue in way of positive value culture, third key success reliability factor is to look into student's problems and try to provide a solution promptly reflect the sharing with all key stakeholders jointly care and cure instead of telling the problem mode to shifting the paradigm of giving solution is the great concern to win over the situation in the competitive edge real recovery related activities very highly valuable capability one institution prime possession to survive as a the best provider in educational service, fourth priority factor to address have high teaching standards and quality academics invite stakeholder to the process of its creation analyse about excellence in co-creation process, fifth main factor is to deliver its services in relatively small and manageable class sizes related preparatory measure in way of utilization to reach maximum resources to evident of its efficient and effective performance in reinforce the institutions culture of values in all types of situation access facilities and resources, final agree upon empathy is to provide 'value for money' higher educational service as overall performance of higher educational institution in terms of future oriented use of experience, positioning and the process of making student more prominent. So higher educational institution easily satisfy perception level of students than expectation. This will reach exceed the level of student customer satisfaction only then rightly identified service gap. This study identified by these drives, and their contribution to the concept of value. Very particular in higher educational service provider do well in creating value through these service quality dimensionalities then they can create some natural change in the mind set of student customer in positive way, this lead to overall customer satisfaction. Make all those value as a cultural creation from provider side, then any higher educational institutions they can attain the superior in efficiency in their operative level. With regard to this any higher educational institution can easily attain superior in brand positioning. In connection with providers of higher educational institutions can get any good ranking by the rating agencies also easily satisfy any assessment and accreditation council in the competitive edge. Hence, Providers of this pattern can easily achieve success and sustain forever.

\section{REFERENCES}

1. Aslan, S., and Reigeluth, C. M., A trip to the past and future of educational computing, Understanding its evolution. Contemporary Educational Technology, 2(1), (2011), 1-17

2. Baghdadi, Z. D., Best Practices in Online Education, Online Instructors, Courses, and Administrators. Turkish Online Journal of Distance Education, 12(3), (2011),109-117.

3. Barbour, M. K., Portrait of Rural Virtual Schooling. Canadian Journal of Educational Administration and Policy, 59, (2007), 1-21.

4. Black, E. W., Beck, D., Dawson, K., Jinks, S., and DiPietro, M., Considering implementation and use in the adoption of an LMS in online and blended learning environments. TechTrends, 51(2), (2007), $35-53$.

5. Bower, B. L., and Hardy, K. P. From correspondence to cyberspace, Changes and challenges in distance education. New Directions for Community Colleges, 128, (2004), 5-12.

6. Chris Kila. (2015). Impact of Technology on University Student's Life and Academic Progress. Journal of Business and Management. 1 (4), 1-24

7. Christian N. Madu and Chu Hua Kuei, "Dimensions of Quality Teaching in Higher Institutions", Total Quality Management, Vol. 4, No. 3, pp. 325-338, 1993.

8. Coates, H., James, R., and Baldwin, G., A critical examination of the effects of learning management systems on university teaching and learning. Tertiary education and management, 11, (2005), 19-36.

9. Conole, G., and Dyke, M., What are the affordances of information and communication technologies? Association for Learning Technology Journal, 12(2), (2004), 113-124

10. Cowan, J. E., Strategies for planning technology-enhanced learning experiences. The Clearing House, A Journal of Educational Strategies, Issues and Ideas, 82(2), (2008), 55-59.

11. Dutton, W. H., Cheong, P. H., and Park, N., The social shaping of a virtual learning environment, The case of a university-wide course management system. Electronic Journal of e-learning, 2(1), (2004), 69-80.

12. Govindasamy, T., Successful implementation of e-learning,

13. Groff, J., and Mouza, C., A framework for addressing challenges to classroom technology use. AACE Journal, 16(1), (2008), 21-46.

14. Haynes K., Grugulis I., 2014, Managing Services: Challenges and Innovation, Oxford University Press, Oxford.

15. Herse, P., and Lee, A., Optometry and WebCT, a student survey of the value of web- based learning environments in optometric education. Clinical and Experimental Optometry, 88(1), (2005), 4652.

16. Holbrook, M. B., 2005, Customer value and autoethnography: subjective personal introspection and the meanings of a photograph collection, "Journal of Business Research", Volume 58, Issue 1.

17. Husain SalilulAkareem and Syed ShahadatHossain. (2016). Determinants of Education Quality: What Makes Students' Perception Different?. Open Review of Educational Research. 3 (1), 52-67.

18. Jian Han Lim et al. (2017). Automated Classroom Monitoring With Connected Visioning System. Proceedings of Apsipa Annual Summit and Conference. 12 (15), 124-130.

19. Josep Gallifa and Pere Batalle, "Student Perceptions of Service Quality in a Multi-Campus Higher Education System in Spain", Quality Assurance in Education, Vol. 18, No. 2, pp. 156-170, 2010.

20. Keengwe, J., Onchwari, G., and Wachira, P., The use of computer tools to support meaningful learning. AACE journal, 16(1), (2008), $77-92$.

21. Koszalka, T., and Ganesan, R. Designing online courses, A taxonomy to guide strategic use of features available in course management systems (CMS) in distance education. Distance Education, 25(2), (2004), 243-256.

22. Lei, J., and Zhao, Y., One-to-one computing, what does it bring to

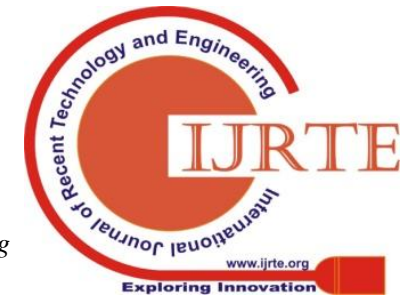


schools? Journal of Educational Computing Research, 39(2), (2008), 97-122.

23. Li, Q., and Ma, X., A meta-analysis of the effects of computer technology on school students' mathematics learning. Educational Psychology Study, 22(3), (2010), 215-243.

24. Lonn, S., and Teasley, S. D., Saving time or innovating practice, Investigating perceptions and uses of Learning Management Systems. Computers and Education, 53(3), (2009), 686-694.

25. Lonn, S., and Teasley, S. D., Saving time or innovating practice, Investigating perceptions and uses of Learning Management Systems. Computers and Education, 53(3), (2009), 686-694.

26. Lou, Y., Bernard, R. M., and Abrami, P. C., Media and pedagogy in undergraduate distance education, A theory-based meta-analysis of empirical literature. Educational Technology Research and Development, 54(2), (2006), 141-176.

27. Michael Tomlinson. (2018). Conceptions of the Value of Higher Education in a Measured Market. High Educ. 7 (5), 711-727

28. Nate Johnson. (2016). Aligning Student and Institution Incentives in Higher Education Finance. Lumina Issue Papers. 1 (1), 1-32

29. P.Shanmugapriyaet al. (2016).Android Application to Student Education Monitoring Device Range and Real-Time Performance Tracking. International Journal of Information Technology \& Mechanical Engineering. 2 (3), 1-7.

30. Reetha.S and Dr.P.Visu.(2017). Student Attendance Marking Using Face Recognition in Internet of Things. International Journal of Computer Science Trends and Technology. 5 (3), 199-204.

31. Rother, C., Evaluating technology's role in the classroom. The Journal, 32(3), (2004), 43-49.

32. SagarRajebhosaleet al. (2016). Smart Campus - An Academic Web Portal With Android Application. International Research Journal of Engineering and Technology. 3 (4), 389-394

33. SnehalKekaneet al. (2016). Automatic Student Performance Analysis and Monitoring. International Journal of Innovative Research in Computer and Communication Engineering. 4 (1), 1-6.

34. Vargo, S. L., Lusch R. F., 2004b, Evolving to a new dominant logic for marketing, "Journal of Marketing", Volume 68, January.

35. Vargo, S. L., Lusch R. F., 2008, Service-Dominant Logic: Continuing the Evolution, "Journal of the Academy of Marketing Science", Volume 36.

36. Vikrant Kumar Kaushik et al. (2017). Student Leave Management System. International Conference on "Research Avenues in Social Science. 3 (5), 124-130.

37. Wang, M. J., Designing online courses that effectively engage learners from diverse cultural backgrounds. British Journal of Educational Technology, 38(2), (2007), 294-311.

38. Wenglinsky, H., Technology and achievement, the bottom line. Educational Leadership, 63(4), (2005), 29.

\section{AUTHORS PROFILE}

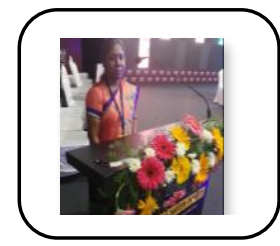

Dr. B. Shanmuga Priya received her $\mathrm{Ph} . \mathrm{D}$ degree awarded in Management Studies from Kalasalingam Academy of Research and Education in 2017. She has qualified UGC NET in management in 2010. She has received young scientist fellowship award by Tamilnadu state council of Science and Technology. She has attended several national and international conferences and has presented 3 papers in BITS Pilani, Pilani Campus, Rajasthan in 2015, International conference on Excellence in Research and Education, IIM INDORE in 2013, and national level Doctoral Conference in Viswakarma Institute of management in 2011 in addition to that, presented many research papers. She has certified on Use of ICT in online and blended learning in education by IIT BOMAY. Impartus effective Utilization Award for Adapting video lecture capture and being the digital revolution in education by Impartus lecture capture solution, Bangalore in 2018. She has published 6 papers in International journal especially Singapore and Malaysia A-category journal. She has delivered lecture through video conferencing on Services quality dimension in Higher Education Institutions for Acharya B-School, Bangalore. She has received best faculty award by IARA in 2018 , Young Scientist Award and A.P.J.Abdul Kalam Award in 2019. 